\title{
Power company leaves environmental legacy
}

\section{London}

ENVIRONMENTAL researchers across Britain have received some $£ 1.8$ million (US\$3.1 million) worth of equipment as a result of the privatization last year of Britain's public utility. But their happiness with the windfall is tempered by the dissolution of one of the world's largest acid rain research laboratories, and the government's failure to compensate for such losses by increasing its spending on environmental research.

Last year, National Power - formerly part of the publicly owned Central Electricity Generating Board (CEGB) decided to scale down dramatically its research activities after privatization (Nature 352, 460; 1991). Research programmes that were meant to solve national problems or deal with international issues fell outside the company's concern, it announced, and were to be discontinued. Only research essential for its core business of generating electricity would remain.

Since then, a large proportion of the equipment has been distributed through the Natural Environment Research Council (NERC). Around 160 items - including a number of large, sophisticated controlled environments for studying the effects of pollutants on plants and their movements through soils - have been shared by 27 different groups, including university departments, the Forestry Commission and NERC's own terrestrial and fresh-water institutes.

In a separate deal, staff and $£ 30,000$ in equipment have gone to Imperial College, London, to form an atmospheric chemistry research unit. The package includes a share in a Jetstream aircraft, fitted out for observing plumes from industrial sources or cities and for large-sale studies of tropospheric pollutants.

The group, which also brought with it

\section{New court challenge for $\mathrm{OSI}$}

\section{Washington}

THE embattled scientific misconduct office at the US National Institutes of Health (NIH) has been sued again, this time in a class-action filing that could affect misconduct cases throughout the United States.

Herbert Needleman, a University of Pittsburgh lead researcher, filed suit late last month against his university and NIH, claiming that the NIH misconduct rules are being imposed retroactively and in violation of federal rule-making regulations. Needleman is under investigation by the university at the request of NIH's Office of Scientific Integrity (OSI). The university is reviewing allegations that Needleman misrepresented data in two studies - one in 1979, the other in 1990 - on the effect of lead on children's intelligence. A victory for Needleman would invalidate the OSI rules nationwide.

By filing a class-action suit, Needleman and his lawyer, James Lieber of the Pittsburgh law firm Lieber \& Hammer, are claiming to represent "all those scientists who are or will be charged with misconduct" by OSI, Lieber says. Class-action suits are permitted in cases where the number of parties claiming substantially similar injury are too numerous to name. In practice, that has traditionally meant about 50 or more.

Needleman wants to have the NIH rules invalidated and his investigation halted, but he is not seeking monetary damages. One advantage to plaintiffs in a classaction suit is that legal costs can be shared, but such a savings is not the motivation in this suit, says Lieber. "It's not an economic question, it's a legal question", he says.

OSI's regulations have been declared illegal in one previous case - that of James Abbs, a University of Wisconsin researcher - but in that case (which is still under appeal) OSI was prevented from exercising its authority only in one district in Wisconsin. A similar suit, if filed in a federal court in Washington DC, would have nationwide impact.

But Needleman wants to halt the university's investigation as well, so he is filing in a Pittsburgh court. Calling a class action suit an "altruistic" action, Lieber says the blanket approach is intended to save other researchers from filing "piecemeal litigations up and down the country."

Needleman is claiming that a definition of misconduct published in 1990 by OSI should not be applied to research that was conducted a decade earlier. The rules are also impossibly vague, Lieber argues; catch-all definitions such as "any other practices that seriously deviate from the norm" are invalid under a US law that governs such ambiguous phrases, he says.

Responding to faculty support for Needleman, Pittsburgh agreed last month to open the investigative proceedings to the general public. Although open hearings (which begin on 13 April) do not satisfy Needleman's demands for due process, he hopes that either his suit or continuing negotiations with the university will eventually result in such rights as cross examination and written charges.

Christopher Anderson
$£ 50,000$ in start-up money from National Power, is keen to continue the work it was doing under the company. This includes a number of cooperative ventures with the European Commission, such as examining the dispersion of pollutants over complex terrains such as the Alps.

National Power also put money into a plan by senior staff at its Fawley marine laboratories to transform themselves into a commercial operation, offering contract research and monitoring services to power and water companies both in the UK and in Europe. Donations of more conventional laboratory equipment went to university departments and hospitals in Britain and to Charles University in Prague.

Although this seems like a story where everyone benefits, there are some discordant voices. Some observers say that National Power is just off-loading equipment otherwise intended for the scrapheap. They add that the benefit does not outweigh the loss of the research work carried out under the old CEGB. Certainly one of the world's largest acid rain teams (with an annual budget of $£ 4.5$ million) has been lost, and a vague statement by the government that it would take up the slack in funding environmental research dropped by the power companies has not been realized.

But officials at National Power say that much of the CEGB research had come to a natural end. Work related to decisionmaking - the consequences of continuing with large, coal-fired plants and adopting combined-cycle gas turbines - ended because the decisions had been made. Similarly, clear environmental objectives from the EC removed the need for the company to set its own standards. What still needs to be done, they say, can be farmed out.

"Increasingly, universities and other institutions are more geared up to provide that research, so it is easier to contract out," says a spokeswoman for the company. National Power's remaining scientists, relocated to its Swindon offices, will be involved in "keeping a finger on the pulse" of what is going on but will do very little hands-on research. The utility company has not decided how much it intends to spend on outside research. Ian Mundell

\section{Correction}

In the News story "NIH staffer finds warm reception on other side" (Nature 355, 98; 9 January 1992), the date mentioned for the meeting between National Institutes of Health (NIH) officials and Congress should have been 4 November 1991. Nature was similarly wrongly informed that there had been an "exchange" of letters between the NIH and Congress; in fact, NIH have yet to respond to the congressional letter. Elsewhere in the story, an ambiguous sentence could have been read to mean that Walter Stewart, an NIH employee, was not paid by $\mathrm{NIH}$ while he was temporarily assigned to work for Congress. In fact, Stewart remained on the NIH payroll throughout his assignment. 